\title{
TECHNOLOGICAL PROPERTIES OF CERAMIC SLURRIES BASED ON ALUMINIUM III OXIDE FOR CERAMIC SHELL MOULDS FABRICATION
}

\section{WŁAŚCIWOŚCI TECHNOLOGICZNE MIESZANEK CERAMICZNYCH NA BAZIE TLENKU GLINU III STOSOWANYCH DO PRODUKCJI CERAMICZNYCH FORM ODLEWNICZYCH}

\author{
Marcin MAŁEK ${ }^{1}$, Paweł WIŚNIEWSKI ${ }^{1}$, Hubert MATYSIAK ${ }^{2}$, \\ Krzysztof Jan KURZYDŁOWSKI ${ }^{1}$
}

\begin{abstract}
In this work technological properties of ceramic slurries based on aluminium III oxide were characterized. Alumina with two different granulation (030\# and 200\#) in ratio $(50 \%-50 \%, 35 \%-65 \%$ and $65 \%-35 \%$ by weight) was used for preparation ceramic slurries. Solid phase was $72.5 \%$ by weight. Technological properties like viscosity, dynamic viscosity, $\mathrm{pH}$ plate weight test and density were investigated. For characterization alumina SEM images, chemical composition and grain size, Zeta potential were done. Aluminium III oxide based ceramic slurries had very promising properties and there are very perspective for future application.

Financial support of Structural Funds in the Operational Programme - Innovative Economy (IE OP) financed from the European Regional Development Fund - Project "Modern material technologies in aerospace industry", No. POIG.01.01.02-00-015/08-00 is gratefully acknowledged.
\end{abstract}

Keywords: ceramic slurry, aluminium III oxide, technological properties

Streszczenie: W artykule przedstawiono wyniki właściwości technologicznych mieszanek ceramicznych na bazie tlenku glinu. Do przyrządzenia mas lejnych użyto $\mathrm{Al}_{2} \mathrm{O}_{3}$ o dwóch różnych gradacjach (030 mesh i 200 mesh) w proporcji (50\%-50\%, 35\%-65\% i 65\%-35\% wagowych). Zawartość fazy stałej wynosiła 72,5\% wagowych. Właściwości technologiczne takie jak lepkość, lepkość dynamiczna, $\mathrm{pH}$, test płyty mosiężnej i gęstość zostały zestawione w poniższym artykule. Do charakteryzacji proszków użytych do przygotowania gęstw ceramicznych zostały wykonane badania: SEM, składu chemicznego, wielkości ziarna oraz

\footnotetext{
${ }^{1}$ Faculty of Materials Science and Engineering, Warsaw University of Technology, Woloska 141, 02-507 Warsaw, Poland

${ }^{2}$ Functional Materials Research Centre, Warsaw University of Technology, Janka Bytnara Rudego 25, 02- 647 Warsaw, Poland
} 
potencjału Zeta. Mieszanki ceramiczne na bazie tlenku glinu wykazują obiecujące właściwości oraz mogą być zastosowane w przyszłej aplikacji.

Badania realizowane $\mathrm{w}$ ramach projektu „Nowoczesne technologie materiałowe stosowane w przemyśle lotniczym" nr POIG.01.01.02-00-015/08-00 w Programie Operacyjnym Innowacyjna Gospodarka (PO IG). Projekt współfinansowany przez Unię Europejską ze środków Europejskiego Funduszu Rozwoju Regionalnego.

Słowa kluczowe: mieszanka ceramiczna, tlenek glinu III, właściwości technologiczne

\section{INTRODUCTION}

Investment casting research and development has always focused on improving manufacturing techniques and capabilities of all key elements involved in production process. Without designing new materials for those purposes this goal may not be successfully achieved.

Nowadays, for fabrication ceramic shell molds for investment casting process in the domestic aviation industry, alcohol binder based on the hydrolyzed ethyl silicate (ZKE) is used. Chemically it is a mixture consisting of tetraethylorthosilicate, its products of incomplete hydrolysis and organic compounds of silicon. Ethyl silicate in pure form does not show binding capacity. It is characterized by high hydrolysis efficiency in water, which allows to apply it in the foundry industry. During ethyl silicate hydrolysis the insoluble in water silica is formed. Although silica is chemically inert it effects on the heat resistance and binding capacity of bulk ceramics. The hydrolysis process takes place in the presence of solvents among of which most frequently used are ethyl alcohol, acetone, hydrochloric acid or other strong organic acid. Though the solvent significantly accelerates the process of hydrolysis, it also influences on the human health and work comfort during fabrication ceramic shell molds [1-2].

Ceramic slurries based on ZKE exhibit very useful properties during the forming process:

- high stability of technological parameters,

- short time of each layer drying,

- increase the strength properties of manufactured forms,

- provide high gas-permeability of produced forms,

- ease of knocking out shell molds of ceramic [3-4].

The laboratories for investment casting are conducted research for use water-soluble binders based on nano- $\mathrm{Al}_{2} \mathrm{O}_{3}$. Such binders are characterized by higher melting point and improved dispersion of the particles in water and other inorganic solvents. Moreover these binders also have a higher surface area than binders presently used in foundry [5-6].

Crucial issues for new binders are to control the rheological properties by preventing sedimentation of heavy particles in a ceramic slurries and to enhance mechanical properties of the forms. Furthermore the binder should exhibit a high miscibility of the mixture components, molding ability, durability, and no reactivity with cast alloy. Additionally aspects influencing the choice of a binder are environmental regulations which require the elimination alcohol from binders in favor of water-soluble binder [7-8].

Thus, in investment casting for preparation products of complex geometry multilayer ceramic shell molds are used. Their major features are: adequate gas permeability and durability while pouring liquid metal. There are two main types of layers: 
- first layer (prime coat) - responsible for shape mapping of the casting alloy and it is in direct contact with liquid metal alloy,

- structural layer (backup) - key role of this layer is to provide an adequate mechanical strength, porosity and gas-permeability [2,9].

The basic materials which are most commonly used for the fabrication of ceramic shell molds are aluminosilicates, alumina, zirconia or mullite [1].

\section{EXPERIMENTAL METHODS}

Experiments were carried out with two different grain size of alumina oxides (Treibacher): 030 and 200 mesh, respectively. In addition binder with $\mathrm{Al}_{2} \mathrm{O}_{3}$ nanoparticles (Evonik) was used. Total contribution of the solid phase was $72.5 \mathrm{wt} \%$. In order to characterization the morphology and microstructure of molding powders SEM microscopy studies were performed (using microscope Hitachi SU3500 (Hitachi, Japan) with BSE detector, voltage $25 \mathrm{kV}$ ). Particles size were obtained through the use of laser diffraction device Horiba LA-950 (Hitachi, Japan). Ceramic slurries were produced in a reactor and stirred using a mechanical stirrer. The study was performed with one day time step for better effect of liquefaction. Every day of measurement the evaporated water was supplemented. Ceramic slurries density was determined in aerometer. To identify the adhesive properties of slurries the brass plate was used with dimensions $75 \times 75 \mathrm{~mm}$ and a weight $75.46 \mathrm{~g}$. Drain off the weight of ceramic mass was recorded every 15 seconds with the total measurement time of $180 \mathrm{~s}$. The relative viscosity and dynamic viscosity were tested using, a draw cup Zahn \#4 and Brookfield DV II + (USA), respectively. For this purpose, the method of the coaxial cylinders was used. Rheological properties were tested in increasing speed range of $20 \div 200$ RPM as well as decreasing $200 \div 20$ RPM. Samples $\mathrm{pH}$ were obtained on the $\mathrm{pH}-$ meter equipped with a $\mathrm{pH}$ suspensions electrode. Chemical composition was determined by X-ray fluorescence analysis (XRF) performed on Bruker S4 Explorer X-ray fluorescent spectrometer. The spectrometer is equipped with $\mathrm{Rh}$ tube and a copper anode inside, $\mathrm{Cu}, \mathrm{Pb}$ and $\mathrm{Al}$ filters, $0.23^{\circ}, 0.46^{\circ}, 1^{\circ}$, and $2^{\circ}$ collimators, and LiF200, Ge, PET, and XS-55 crystals. Measurements of basic rheological properties of ceramic slurries were taken over $96 \mathrm{~h}$ in an air-conditioned lab at $21^{\circ} \mathrm{C}$.

\section{RESULTS}

In this study materials used for fabrication ceramic shell molds act as fillers. There were two molding powders $\mathrm{Al}_{2} \mathrm{O}_{3} 030$ and 200 mesh exhibit an average particle size of 11.79 microns and 45.00 microns and were provided by Treibacher. Representative structure images of investigated powders are presented on Figure 1. Table 1 present results of XRF test. Studies by SEM shown that 030 and 200 mesh exhibit typically melted powder sharp-edged structure. Both of powders were characterized high purity, 030 mesh -99.50 wt.\% of $\mathrm{Al}_{2} \mathrm{O}_{3}$ and 200 mesh -99.33 wt. $\%$ of $\mathrm{Al}_{2} \mathrm{O}_{3}$.

Figures $2 \div 4$ presents plate weight test results of alumina based ceramic slurries with three different ratio of alumina powder (35-65 wt.\%; 50-50wt.\%; 65-35 wt.\%). As seen in Figures 2 and 3 the curves profiles are very similar. Plateau was observed at $60 \mathrm{~s}$ of measuring. In Figure 4 at first and second day of test ceramic slurry showed the higher weight. It is believed that ceramic slurry was not well liquefied. Third and fourth day 
of measuring outcomes might confirm that.
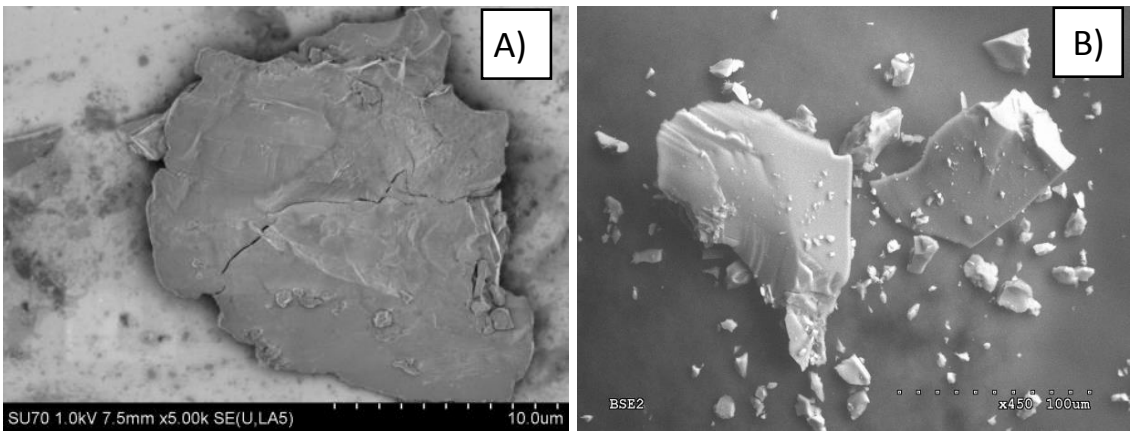

Figure 1. SEM images of investigated alumina powders structure (A - 030 mesh; B - 200 mesh)

Table 1. XRF results of investigated powder

\begin{tabular}{|c|c|c|c|}
\hline \multicolumn{2}{|c|}{$\mathrm{Al}_{2} \mathrm{O}_{3} 030$ mesh } & \multicolumn{2}{|c|}{$\mathrm{Al}_{2} \mathrm{O}_{3} 200$ mesh } \\
\hline Element & wt. $\%$ & Element & wt. $\%$ \\
\hline \multirow{4}{*}{$\mathrm{Al}_{2} \mathrm{O}_{3}$} & \multirow{4}{*}{99.50} & $\mathrm{SiO}_{2}$ & 0.23 \\
\hline & & $\mathrm{Al}_{2} \mathrm{O}_{3}$ & 99.33 \\
\hline & & $\mathrm{Fe}_{2} \mathrm{O}_{3}$ & 0.03 \\
\hline & & $\mathrm{CaO}$ & 0.02 \\
\hline \multirow{4}{*}{$\mathrm{Na}_{2} \mathrm{O}$} & \multirow{4}{*}{0.35} & $\mathrm{MgO}$ & 0.01 \\
\hline & & $\mathrm{Na}_{2} \mathrm{O}$ & 0.20 \\
\hline & & $\mathrm{TiO}_{2}$ & 0.02 \\
\hline & & $\mathrm{Bi}$ & 0.002 \\
\hline \multirow{4}{*}{$\mathrm{Fe}_{2} \mathrm{O}_{3}$} & \multirow{4}{*}{0.05} & $\mathrm{Ni}$ & 0.023 \\
\hline & & $\mathrm{Pb}$ & 0.001 \\
\hline & & $\mathrm{Cr}$ & 0.06 \\
\hline & & $\mathrm{Cu}$ & 0.002 \\
\hline
\end{tabular}

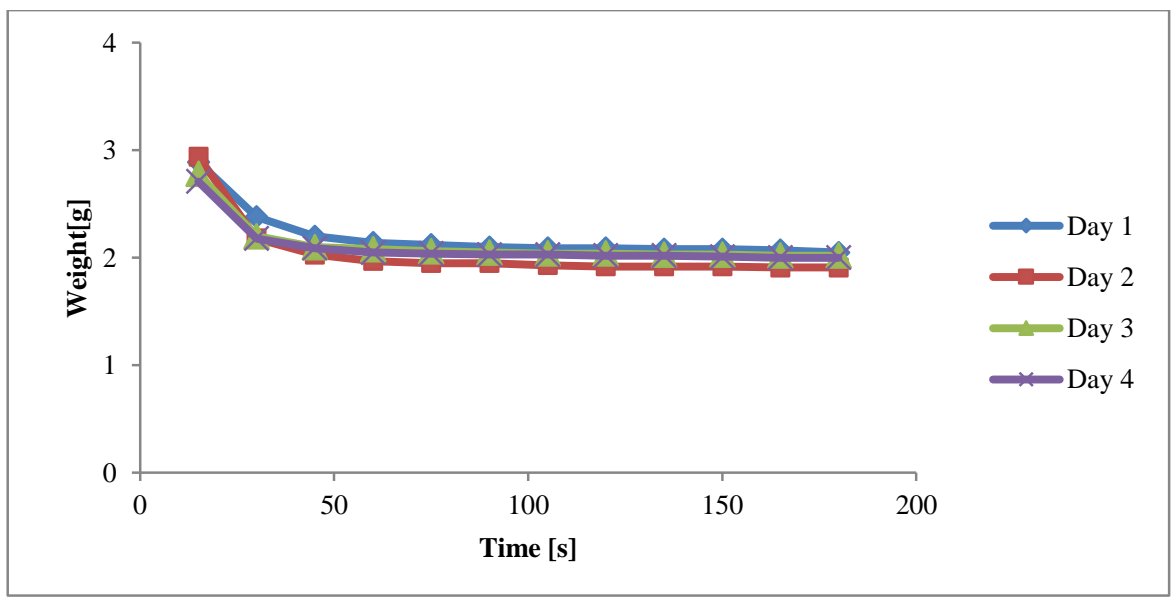

Figure 2. Plate weight test results of alumina slurries with alumina ratio $35-65 \mathrm{wt} \%$ 


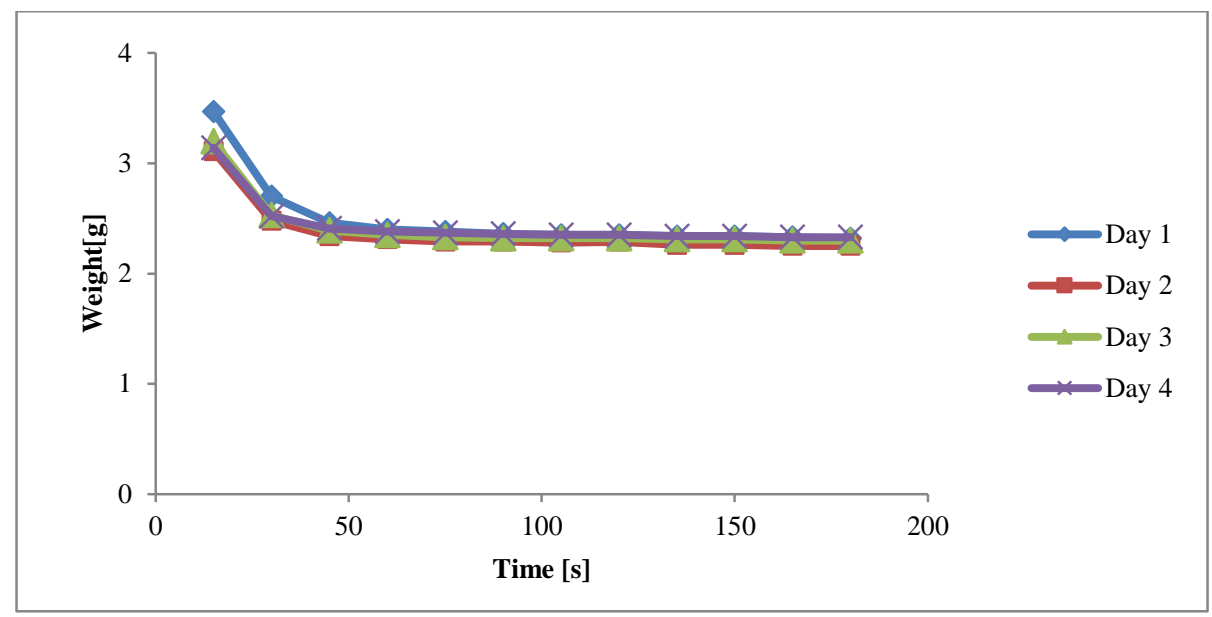

Figure 3. Plate weight test results of alumina slurries with alumina ratio 50-50 wt. $\%$

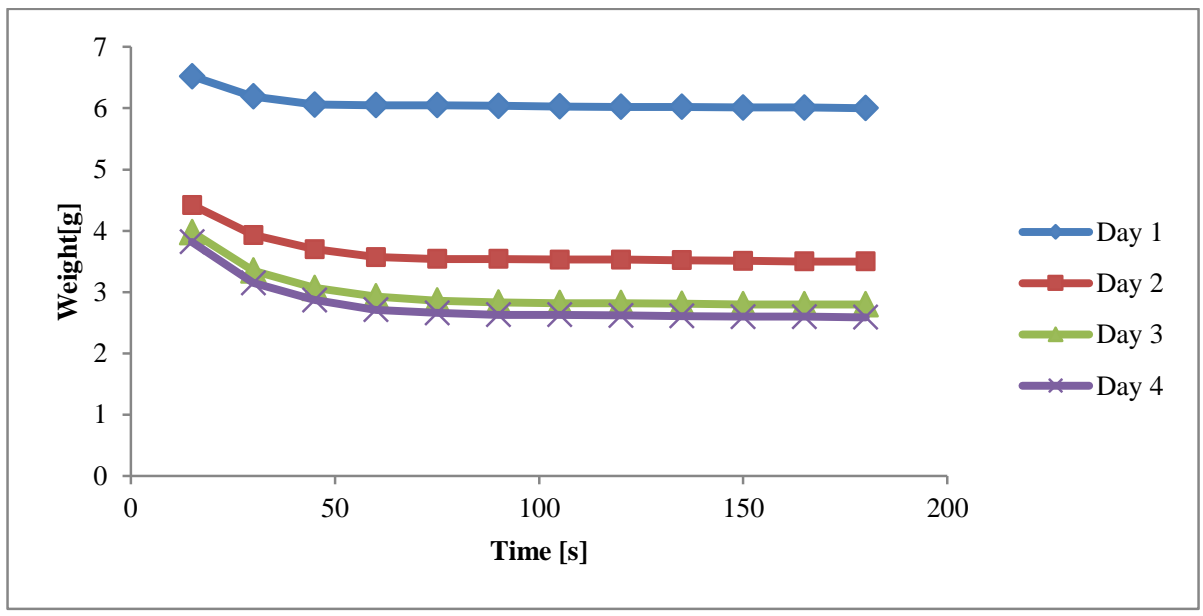

Figure 4. Plate weight test results of alumina slurries with alumina ratio $65-35$ wt.\%

Images of aluminum III oxide based ceramic slurries after dipping test are shown in Figure 5. Excellent quality of surface coverage can be observed. The ceramic slurries were very adhesive on both flat surface and edges.

As seen in Figure 6, ceramic slurries containing 50-50 wt.\% of alumina 030 mesh and 200 mesh revealed the highest viscosity of $5000 \mathrm{mPa} \cdot \mathrm{s}$. With changing the ratio of alumina to 35-65 wt.\% and 65-35 wt.\% dynamic viscosity were decreasing to $200 \mathrm{mPa} \cdot \mathrm{s}$. 


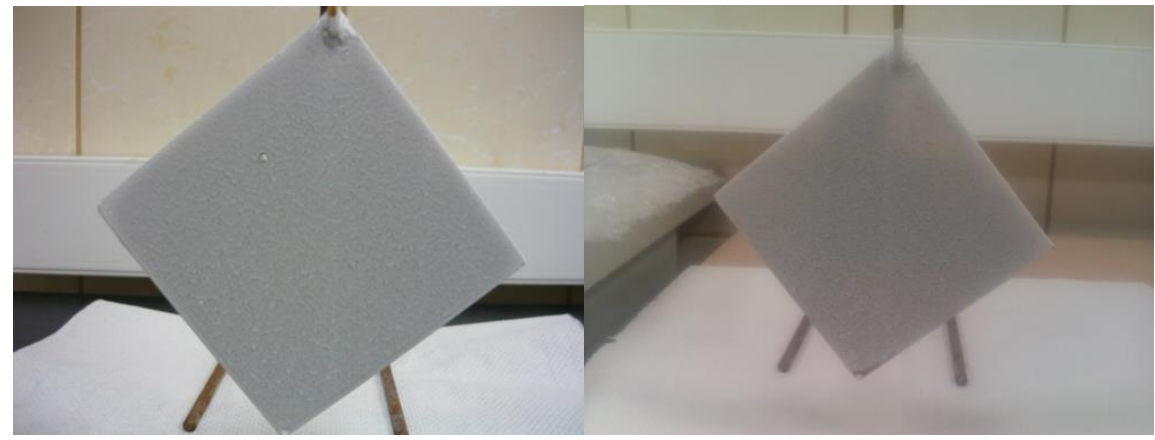

Figure 5. Plate images after the dipping test

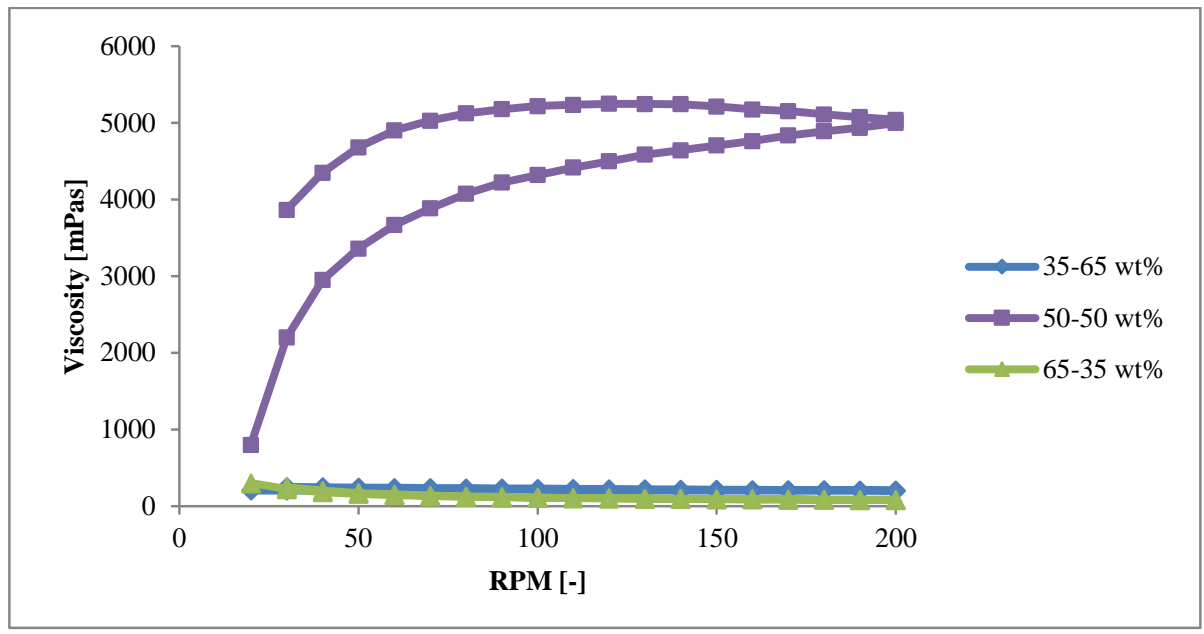

Figure 6. Dynamic viscosity test results of alumina based ceramic slurries

Figure 7 presents the distribution of Zahn Cup viscosity and weight after $120 \mathrm{~s}$. It shows the influence of three different ratio of alumina on ceramic slurries. Dynamic viscosity and weight after $120 \mathrm{~s}$ were decreasing every day of measurement. The highest viscosity exhibit ceramic slurry with 50-50 wt.\% amount aluminum III oxide. However the highest weight after $120 \mathrm{~s}$ revealed for ceramic slurry in ratio of aluminum 65-35 wt.\%. Fourth day of measurement PWT results were similar and are near by $2.5 \mathrm{~g}$.

Figure 8 presents results of parameters such as $\mathrm{pH}$ and density. Curves are very similar. Density and $\mathrm{pH}$ of investigated ceramic slurries are stable on each measurement day. There were no significant changes on the density and $\mathrm{pH}$ parameter. 


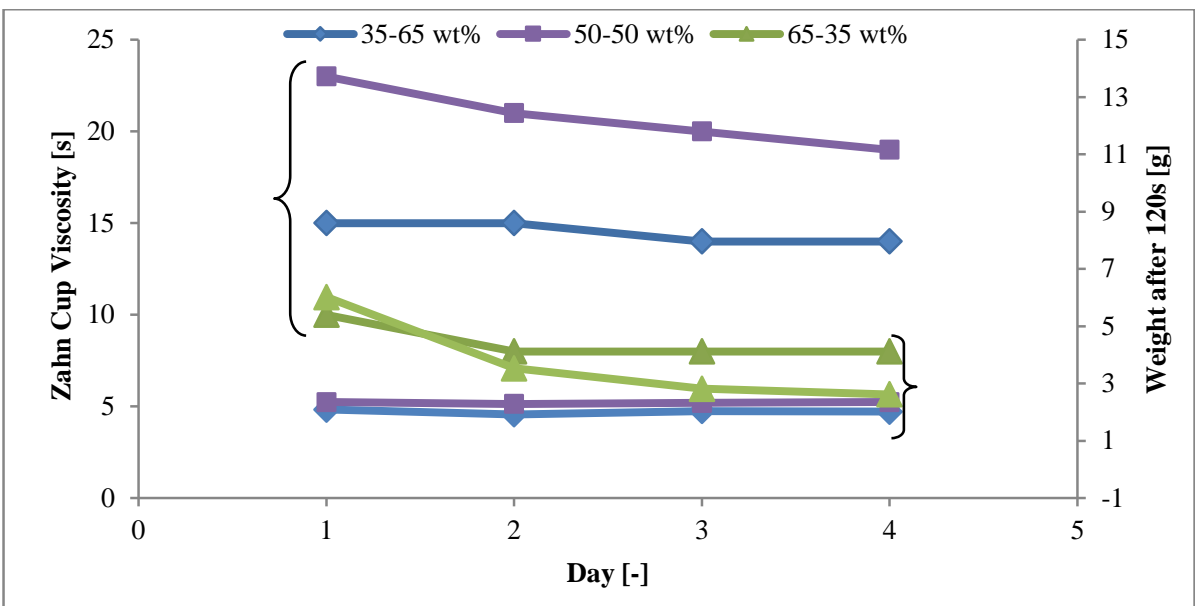

Figure 7. Zahn Cup viscosity and weight after 120 s diagram

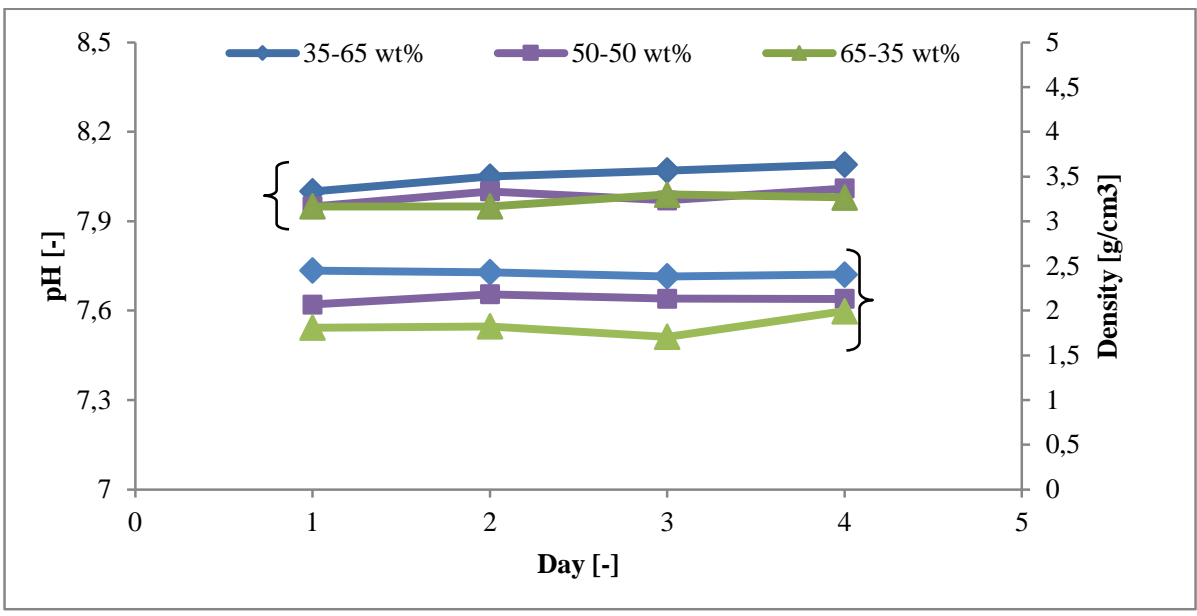

Figure 8. Diagram of $\mathrm{pH}$ and density parameters

\section{SUMMARY}

According to work assumptions, as well as in connection with the industrial requirements, this studies were aimed to develop ceramic slurries, which are characterized by low density, relatively high ceramic powder content and comparatively low economic cost (price). The main aim was to use aluminium III oxide for preparation ceramic slurries for investment casting process. It has been found that most desirable rheological parameters has ceramic slurries with 35-65 wt.\% amount of alumina powders 030-200 mesh. This slurries meets the standard specification in investment casting process on industrial scale. There are very perspective for future shell moulds fabrication. 


\section{ACKNOWLEDGEMENT}

Financial support of Structural Funds in the Operational Programme - Innovative Economy (IE OP) financed from the European Regional Development Fund - Project "Modern material technologies in aerospace industry", No. POIG.01.01.02-00-015/08-00 is gratefully acknowledged.

\section{LITERATURE}

[1] HARATYM R., BIERNACKI R., MYSZKA D., Ekologiczne wytwarzanie dokladnych odlewów w formach ceramicznych, Oficyna Wydawnicza Politechniki Warszawskiej, 2008.

[2] MATYSIAK H., FERENC J., MICHALSKI J.,. LIPIŃSKI Z, JAKUBOWICZ G., KURZYDLOWSKI K.J., Porowatość $i$ wytrzymatość form ceramicznych wykorzystywanych $w$ procesie odlewania precyzyjnego metoda

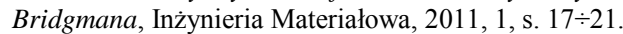

[3] ZAGÓRSKA M., MATYSIAK H., MICHALSKI J., KOPTA M., KUBIAK K., KURZYDŁOWSKI K.J., Właściwości form ceramicznych do odlewania precyzyjnego części lotniczych, wytworzonych w układzie wodnym oraz w etanolu, XXXIX Szkoła Inżynierii Materiałowej, Kraków-Krynica 2011.

[4] KARWIŃSKI A., Wplyw za wartości krzemionki koloidalnej na wlaściwości ciekłej masy ceramicznej stosowanej w technologii wytapianych modeli, Solidification of Metals and Alloys, No.3 1, 1997.

[5] ISMAEL M.R., R.D. dos ANJOS, SALOMAO R. PANDOLFELLI V.C, Colloidal silica as a nostructured

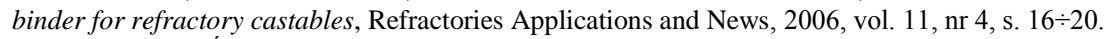

[6] MAŁEK M., WIŚNIEWSKI P., MATYSIAK H., KURZYDŁOWSKI K.J., Lejna mieszanina formierska do produkcji warstw przymodelowych ceramicznych form odlewniczych na osnowie tlenku itru oraz spoiwa zawierajacego nanoczastki tlenku glinu. P.407541 (2014).

[7] MAŁEK M., ZAGÓRSKA M.,, WIŚNIEWSKI P., MATYSIAK H., MICHALSKI J., KURZYDŁOWSKI K.J., Analiza porównawcza spoiw formierskich na bazie krzemionki koloidalnej stosowanych do budowy form ceramicznych do odlewania precyzyjnego części turbin lotniczych, XL Szkoła Inżynierii Materiałowej, Kraków 2012.

[8] ZAGÓRSKA M., MAŁEK M., WAWULSKA P., MATYSIAK H., MICHALSKI J., KURZYDŁOWSKI K.J., Charakterystyka właściwości form ceramicznych wytworzonych na bazie wodnych spoiw Keysol i Matrixso, XL Szkoła Inżynierii Materiałowej, Kraków 2012.

[9] MATYSIAK H., FERENC J., LIPIŃSKI Z., GRABARZ K., MICHALSKI J., KURZYDŁOWSKI K. J., Development of new ceramic slurries and shell moulds for Bridgman casting of turbine blades, Proceedings of European Conference On Materials and Structures In Aerospace, Germany, 2010.BRANDT A.M., The use of experimental mechanics of damage for cement-matrices composites. In: Mechanics of semi-concrete composites, A.M. Brandt (ed.), Wrocław, Ossolineum, 1983, 449-501. 